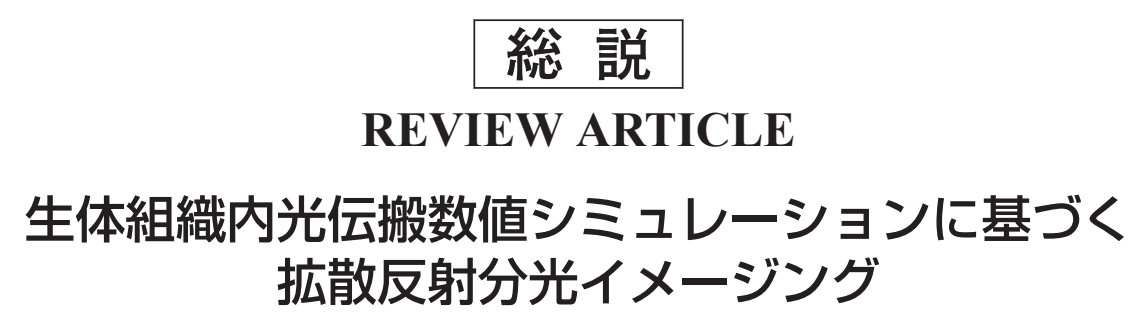

\author{
西舘 泉 $^{1}$, 川内 聡子 $^{2}$, 佐藤 俊一 $^{2}$, 佐藤 学 $^{3}$, \\ 新関 久- 3 , 相津 佳永 4 \\ 1東京農工大学大学院生物システム応用科学府 \\ 2 防衛医科大学校 防衛医学研究センター生体情報・治療システム研究部門 \\ ${ }^{3}$ 山形大学大学院 理工学研究科 \\ 4室蘭工業大学大学院もの創造系領域・ロボティクスユニット
}

(2019 年 8 月 8 日受付，2019 年 9 月 17 日掲載決定，2019 年 11 月 14 日 J-STAGE 早期公開)

\title{
Spectral Diffuse Reflectance Imaging Based on Numerical Simulation for Light Transport in Biological Tissues
}

\author{
Izumi Nishidate ${ }^{1}$, Satoko Kawauchi², Shunichi Sato ${ }^{2}$, Manabu Sato ${ }^{3}$, \\ Kyuichi Niizeki ${ }^{3}$, Yoshihisa Aizu ${ }^{4}$
}

${ }^{1}$ Graduate School of Bio-application \& Systems Engineering, Tokyo University of Agriculture and Technology
${ }^{2}$ Division of Bioinformation and Therapeutic Systems, National Defense Medical College Research Institute
${ }^{3}$ Graduate School of Science and Engineering, Yamagata University
${ }^{4}$ College of Design and Manufacturing Technology, Robotics Research Unit, Muroran Institute of Technology

(Received August 8, 2019, Accepted September 17, 2019, Advance Publication released online November 14, 2019)

\section{要 旨}

拡散光スペクトルを利用した計測法では，丸ごとの生体や生きた細胞・組織から得られる吸収・散乱スペクトル情 報を解析することで生体の機能および組織形態を評価することができる，中でも，定常白色光源を用いた拡散反射分 光法は簡易・安価な計測システムで実現可能であり，イメージングへの展開も容易である. 本稿では，生体内の光伝 搬数值シミュレーションに基づく拡散反射分光法により, 生体内の血行動態や細胞・組織の形態変化を in vivoで評価 するための方法とその生体医用イメージングへの応用について，著者らの研究を中心に概説する.

キーワード : 拡散反射分光法, 光伝搬モンテカルロシミュレーション, 重回帰分析, 光学特性值, 分光イメージング

\begin{abstract}
Diffuse optical spectroscopy provides functional and morphological information of living tissues based on optical absorption and scattering properties. Diffuse reflectance spectroscopy (DRS) can be achieved with simple and low cost equipment, and has been widely applied to in vivo measurements and imaging of biological tissues. In the present article, in vivo evaluation of hemodynamics and changes in tissue morphology by using DRS based on the Monte Carlo simulation for light transport in biological tissues and its application to biomedical imaging are described.
\end{abstract}

Key words: diffuse reflectance spectroscopy, Monte Carlo simulation for light transport, multiple regression analysis, optical properties, multispectral imaging

干 184-8588 東京都小金井市中町 2-24-16 TEL: 042-388-7065, FAX: 042-388-7065

(2-24-16, Naka-cho, Koganei, Tokyo 184-8588, Japan)

Corresponding author: inishi@cc.tuat.ac.jp（西舘 泉) 


\section{1. はじめに}

生体内に含まれる主要な色素蛋白（以下，色素と呼ぶ) は, Fig.1 に示すように, 可視・近赤外波長域に扔いて固 有の特徵的な吸光スペクトルを有している ${ }^{1)}$. 血管を流 れる血液中のへモグロビンは末梢組織への酸素輸送体と して生体に打ける重要な役割を担って打り, 酸素との結 合状態により吸光スペクトルが異なる。また，メラニン は紫外線に対するバリアとして機能して打り，日焼けや シミ，皮膚癌などと関係している。一方で，生体組織の 多くは可視・近赤外波長域において, 波長の増加に対し て光散乱強度が緩やかに減少する分光特性 2,3)を有してお り, 組織を構成する細胞, 細胞内小器官, 膜などの微細 構造やそれらのサイズと関係している. 生体組織を伝搬 する光はこれらの微細構造により多重散乱されると共に, その一部は色素により吸収される。 そのため，拡散光ス ペクトルには，観測領域に存在する複数の色素の吸光ス ペクトルとそれらの量が反映される．拡散光スペクトル を利用した計測法では，丸ごとの生体や生きた細胞・組 織から得られる吸収・散乱スペクトル情報を解析するこ とで生体の機能打よび組織形態変化を評価することがで きる. 中でも, 定常白色光源を用いた拡散反射分光法 (Diffuse reflectance spectroscopy: DRS) は簡易・安価な計 測システムで実現可能であり，イメージングへの展開も 容易である. 本稿では, 生体内の光伝搬解析に基づく拡 散反射分光法により, 生体内の生理的変化に対する色素 の動態や細胞・組織の形態変化を評価するための方法と イメージングへの応用について, 著者らの研究を中心に 述べる. また, 光学的診断・治療法の開発や較正におい て有用な光学的ファントムについても概説する.

\section{In vivo 測定における光伝搬数值解析}

測定した拡散反射光スペクトルから, 吸収や散乱に関 する情報を抽出し, 定量化するためには, 生体組織中の 光の伝搬を解析する必要がある. そのための有効な手法 の一つとして, 光伝搬モンテカルロシミュレーション $(\mathrm{MCS}){ }^{4)}$ が広く利用されている. これは光を光子のよう に，あるエネルギーをもつ粒子と考え，それが散乱体に
より散乱され方向を変え，また，吸収によりエネルギー を失いながら組織中を進んでいく過程を光学特性值とコ ンピューター内で生成した一様疑似乱数に基づき逐一追 跡する数值計算方法である. 色素のモル吸光係数スペク トル $\varepsilon(\lambda)$ と色素濃度 $C$ の積で表わされる吸収係数スペク トル $\mu_{a}(\lambda)$, 散乱係数スペクトル $\mu_{s}(\lambda)$, 非等方性パラメー ター $g$, 等価散乱係数スペクトル $\mu_{s}{ }^{\prime}(\lambda)$ などの光学特性 值, 対象とする組織構造の幾何学的条件を与えることで, 生体組織の任意の位置・領域から出射した拡散反射率又 ペクトル $R(\lambda)$ や透過率スペクトル $T(\lambda)$ を数值的に求める ことが出来る. Fig.2にメラニンを含む表皮層と酸素化へ モグロビンおよび脱酸素化へモグロビンを含む真皮層の 二層構造でモデル化したヒト皮膚の $R(\lambda)$ を MCS で再現 した一例を示す. MCS は測定值から対象の光学特性值 や色素量を推定するために利用することも可能である. 対象の厚さが十分小さい組織切片や培養組織を扱う in vitro 測定の場合， $R(\lambda)$ や $T(\lambda)$ の測定值と一致するように MCS による計算を繰り返し行い $\mu_{a}(\lambda)$ と $\mu_{s}{ }^{\prime}(\lambda)$ を推定する Inverse Monte Carlo simulation（IMCS）が利用される。一 方 in vivo 測定では， $R(\lambda)$ のが測定される場合がほとん どであるため, IMCS を利用することは困難である。そ のため, $\mu_{a}(\lambda)$ または $C$ と $\mu_{s}^{\prime}(\lambda)$ の様々な組み合わせの下 で多数の $R(\lambda)$ を計算し, 光学特性値と $R(\lambda)$ の関係を決定 しておくことで, $R(\lambda)$ の測定値から光学特性値を推定す る方法が利用される。 その場合, 非線形最適化法, Look up table, 重回帰分析による推定式の作成などが行われる.

\section{3. 生体医用光学技術のための光学ファントム}

生体医用光学分野に拄いて, 新しい光学的計測法, 診 断法，治療法を開発する上で，定量性を含めた性能評価 は不可欠であるが，その場合，光学ファントムによる実 験が有用となる. 光学ファントムとは, 人間や動物など の生体組織と類似した光学特性を有する人工的なモデル の総称であり, 現在までに多くの研究者が独自の方法で 様々な光学ファントムを作成し, 個々の研究において使 用している. また, 生体医用光学分野の国際会議 SPIE Photonics West BiOS に扔いても光学ファントムに特化し

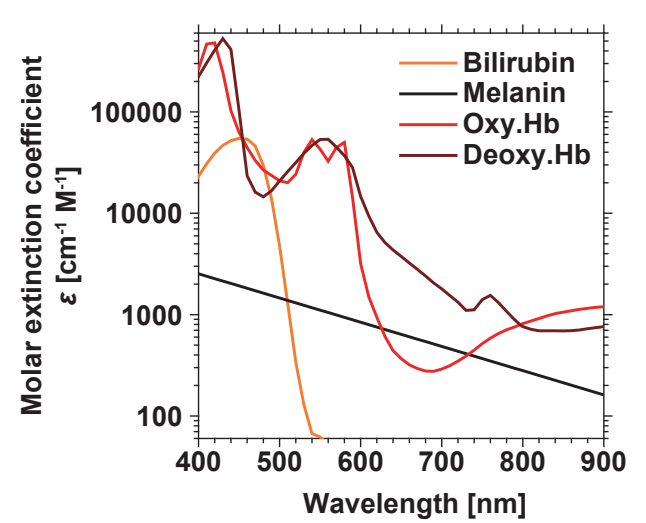

(a)

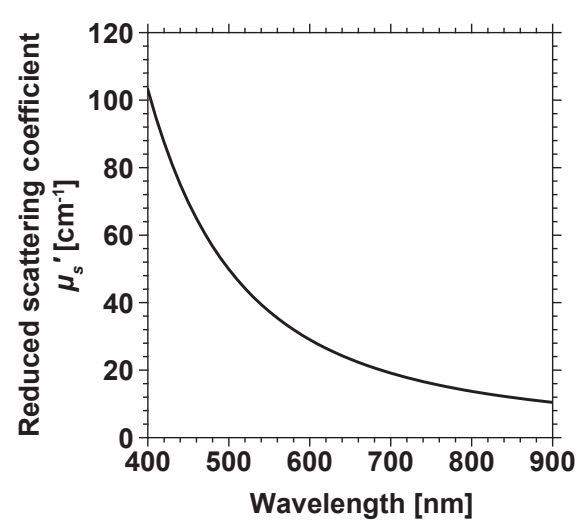

(b)

Fig.1 The molar extinction coefficient spectra of typical biological chromophores and the reduced scattering coefficient spectrum of soft tissue. 

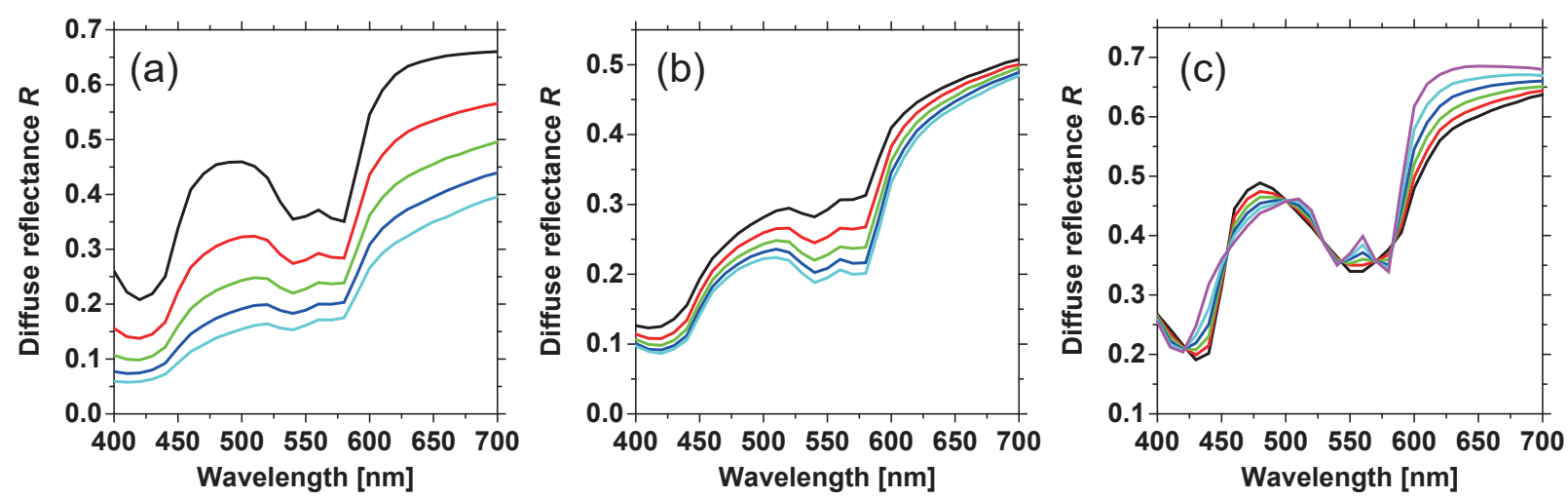

Fig.2 An example of representative simulated diffuse reflectance spectra obtained from the two-layered skin tissue models having different conditions for (a) the concentration of melanin $C_{m}$, (b) the concentration of total hamoglobin $C_{h b t}$, and (c) the tissue oxygen saturation $\mathrm{StO}_{2}$.

たセッションが設けられており，近年その重要性はます ます高まりつつある。これまでに論文等で発表されてい る主な光学ファントムについて, 用途, 材料, 特性等が わかりやすくまとめられている文献もある5).

光学ファントムの主な用途は, 物理モデル・シミュレー ションの妥当性の確認, 機器の性能評価と最適化, 機器 較正と安定性・再現性の試験, 異なる研究機関・研究室 間の比較と標準化である. また, 光学ファントムに求め られる特性としては以下が挙げられている。

（1）吸収・散乱特性を任意に設定できる

（2）生体組織と類似した分光特性を有する

（4）時間・環境条件に対する安定性を有する

（5）生体組織と類似した屈折率を有する

（6）異なる光学特性を持つ複数領域の組み合わせが可 能（腫瘍，血管，皮膚などの多層構造を再現)

（7）生体組織と類似した機械的特性・表面特性

（8）ブラウン運動や流れの内部形成が可能

（9）生体組織と類似した熱的特性を有する

（10）作成のしやすさ

(11) 安価

（12）可搬性

上記の条件をすべて満足するのは難しいため, 実際は個々 の目的に最低限必要な特性を持つように設計することに なる。ファントムが必要とされる多くの場合には, 散乱 や吸収などの光と生体組織の相互作用を扱うため，(1) と (2) の特性は特に重要であると言える. 生体組織の吸 収係数 $\mu_{a}$, 散乱係数 $\mu_{s}$ 非等方性パラメーター $g$, 等価散 乱係数 $\mu_{s}{ }^{\prime}\left[\mu_{s}^{\prime}=(1-\mathrm{g}) \mu_{s}\right]$ を再現するために，これまで に様々な材料が使用されている。

ほとんどの光学ファントムは, 散乱体, 吸収体, とそ れらを維持・固定する基質から構成され, 内部での散乱 体や吸収体の濃度を調整することで, 散乱係数や吸収係 数の設計が可能である. ファントムには生理食塩水や精 製水などの液体，ゼラチン，寒天，ポリアクリルアミド 等のハイドロゲル，エポキシ樹脂，ポリエステル樹脂， ポリウレタン樹脂, シリコンなどの固形状の基質が使わ れる, 液体执よびハイドロゲルを基質としたファントム では，生体組織に近い光散乱特性を有し，その分光特性
も明らかにされているイントラリピッド溶液（またはイ ントラリポス溶液）が光散乱体として多用される. 生体 内の色素蛋白による吸光を再現するためにファントムに 使用される吸光体には，インク，染料，墨汁，へモグロ ビン色素, 全血液が挙げられる。 また, 酸素化へモグロ ビン色素の脱酸素化には $\mathrm{Na}_{2} \mathrm{~S}_{2} \mathrm{O}_{4}$ が用いられることが多 い.これらの材料には相性があるので, どのようなファ ントムを作成するかによって, 基質, 散乱体, 吸収体を 選択する必要がある。例えばレーザーを光源とした拡散 光卜モグラフィで用いるファントムでは，測定部位の形 状，層構造や内部構造を再現する必要があるが，光学特 性は使用波長での值のみを考えればよいため, 吸収体と してインクや染料を利用し，散乱体と混合した上で樹脂 により所望の形状に固めたものが多い ${ }^{6-9)}$.

一方で, 八ロゲンランプや白色 LED 等の白色光源を使 用して, 生体組織の分光分布を計測するような場合には, 1 つのファントムで広範囲のスペクトル特性を再現する 必要が生じる。 そのため, 吸収体としては生体組織と同 様に血液または精製したへモグロビン色素が用いられる。 この場合, ゼラチンや寒天などの八イドロゲルを基質と して利用することが可能である. Fig.3 は皮膚の分光計測 法を評価するために筆者の研究室で使用している光学 ファントムの写真である. 生理食塩水に溶解した寒天, イントラリピッド，血液を組み合わせて作成したこれら のファントムは二層構造と内部血液構造を併せ持ち, か つ皮膚の反射スペクトルを再現することが可能である10). 以上は，主に拡散光の使用を前提としたファントムであ るが, 光干渉断層像 (OCT) 用 ${ }^{11)}$, 超音波変調光卜モグ ラフィ用 ${ }^{12)}$, 光音響卜モグラフィ用 ${ }^{13)}$ のファントムも報 告されている.

\section{4. 拡散反射スペクトル解析による皮膚のメラニン・ヘモ グロビンの定量計測}

皮膚の分光反射率 $R(\lambda)$ は，入射光強度 $I_{0}(\lambda)$ と表皮打よ び真皮を伝搬し，再び表面から出射した後方散乱光強度

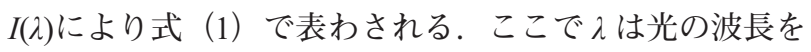
表す. 

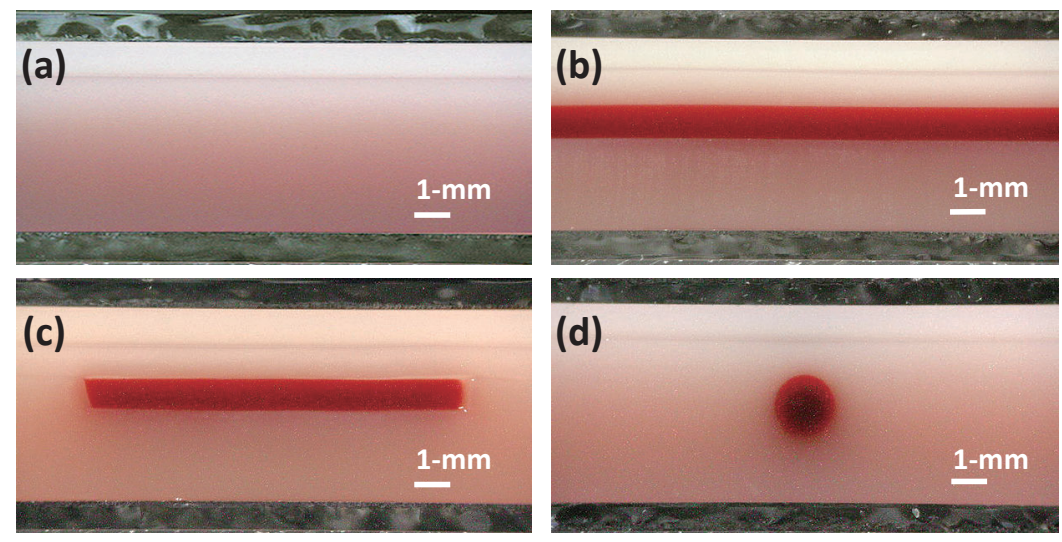

Fig.3 Cross-sectional photographs of skin tissue phantoms: (a) a two-layered phantom, (b) a four-layered phantom, (c) a twolayered phantom with a disc-shaped blood region, and (d) a two-layered phantom with a cylindrical blood region.

$$
R(\lambda)=I(\lambda) / I_{0}(\lambda)
$$

皮膚の内部における光の吸収量に対応する吸光度スペク トル $A(\lambda)$ は分光反射率 $R(\lambda)$ を用いて式 (2) により表わさ れる。

$$
A(\lambda)=-\log _{10} R(\lambda)
$$

ここで，皮膚内部での光の吸収が表皮内のメラニン，真 皮内の酸素化へモグロビン，および脱酸素化へモグロビ ンにより生じると仮定すると, Lambert-Beer 則により $A(\lambda)$ は式（3）により表わされる。

$$
\begin{aligned}
A(\lambda)= & C_{m} l_{e}(\lambda) \varepsilon_{m}(\lambda)+C_{h b o} l_{d}(\lambda) \varepsilon_{h b o}(\lambda) \\
& +C_{h b d} l_{d}(\lambda) \varepsilon_{h b d}(\lambda)+S(\lambda)
\end{aligned}
$$

ここで $C, l(\lambda), \varepsilon(\lambda)$ はそれぞれ色素濃度, 平均光路長お よびモル吸光係数を，また $S(\lambda)$ は散乱による減衰項を表 わす. 添字 $m, h b o, h b d$ はそれぞれメラニン, 酸素化へ モグロビン，脱酸素化へモグロビンであり，e，d は表皮 と真皮を表わす。ここで，実測值 $A(\lambda)$ を目的变数とし， 既知の吸光係数 $\varepsilon_{m}(\lambda), \varepsilon_{h b o}(\lambda)$, および $\varepsilon_{h b d}(\lambda)$ を説明変数 とした重回帰分析（MRA1）を行なうことで，式（4）の 重回帰式が得られる.

$$
A(\lambda)=a_{m} \varepsilon_{m}(\lambda)+a_{h b o} \varepsilon_{h b o}(\lambda)+a_{h b d} \varepsilon_{h b d}(\lambda)+a_{0} .
$$

回帰係数 $a_{m}, a_{h b o}, a_{h b d}$ および $a_{0}$ は $A(\lambda)$ に対する各色素 のモル吸光係数スペクトルおよび散乱による減衰項の寄 与の度合い表しており，色素濃度に関係する。しかしな がら, 平均光路長 $l(\lambda)$ は波長 $\lambda$ の関数であり, また色素 濃度にも依存するため, 回帰係数と色素濃度は非線形な 関係にあり，回帰係数から色素濃度を単純に求めること は困難である。そこで，この回帰係数を新たな変数とし て，メラニン濃度 $C_{m}$ と全へモグロビン濃度 $C_{h b t} \quad\left(=C_{h b o}\right.$ $\left.+C_{h b d}\right)$ の算出に利用する. この場合, $C_{m}=\mathbf{b}_{\boldsymbol{m}} \cdot \mathbf{a}$ および $C_{h b t}=\mathbf{b}_{\boldsymbol{h b t}} \mathbf{a}$ という2 つの推定式を考える. ここで, 数式 中の・は内積を表す. $\mathbf{a}$ は $a_{m}, a_{h b t}\left(=a_{h b o}+a_{h b d}\right), a_{0}$ と
それらの高次項を含むべクトルを表わす．また $\mathbf{b}_{\boldsymbol{m}}$ およ び $\mathbf{b}_{h b t}$ は回帰係数から色素濃度を得るための変換べクト ルである. $\mathbf{b}_{m}$ および $\mathbf{b}_{h b t}$ を決定するために，ヒト皮膚分 光反射率の MCS で生成した色素濃度の異なる多数の $A(\lambda)$ データセットを用いた MRA1 を実行し， $C_{m}$ または $C_{t h}$ と a の多数のデータセットを求める.さらに, $C_{m}$ ま たは $C_{t h}$ を目的変数とし, $\mathbf{a}$ を説明変数とした重回帰分析 （MRA2）を行うことで $\mathbf{b}_{\boldsymbol{m}}$ および $\mathbf{b}_{\boldsymbol{h} \boldsymbol{b} \boldsymbol{t}}$ を統計的に決定す る ${ }^{14)}$ 。また，組織中の全へモグロビン濃度に占める酸素 化へモグロビンの割合である組織酸素飽和度は $\mathrm{StO}_{2}=$ $a_{h b o} /\left(a_{h b o}+a_{h b d}\right)$ より算出する.

前述のプロセスを分光反射率画像の各画素に適用する ことで $C_{m}, C_{h b t}$ 扎よび $\mathrm{StO}_{2}$ の画像化が可能となる. 著 者らはこれまでに, 八ロゲンランプ光源, 6 枚の狭帯域 干渉フィルター（中心波長 $\lambda_{\mathrm{c}}=500 ， 520 ， 540 ， 560$, $580,600 \mathrm{~nm})$ を装填したフィルターホイール，モノク ロ CCD カメラから成る計測装置により取得した分光反 射率画像を用いて $C_{m}, C_{h b t}$ および $\mathrm{StO}_{2}$ の画像化が可能 であることを確認している ${ }^{15)}$.

\section{RGB カメラを用いた分光反射率画像の推定と血行動 態観察への応用}

前述の狭帯域干渉フィルターを用いた分光反射率画像 計測では十分な光量を得るための露光時間やフィルター の機械的走查時間により，画像取得時間が制限される. そのため, 血流動態などの早い変化を連続的に観察する ことが困難である。ハイパースペクトルカメラを用いれ ば，より高速な生体組織の分光イメージングが可能であ るが，現在の所，上述の分光方式を用いたイメージング システムに比べ高価である。 一方で，ディジタルカラー カメラにより得られる RGB 画像から，事前に得られて いる対象の分光反射率の統計的性質を利用することで分 光反射率画像を推定する検討も行われている. この場合, 安価かつコンパクトな撮像システムを利用したワン ショットの多波長分光イメージングが可能であり, 臨床 診断の場において幅広い応用が期待できる。ここでは, Wiener 推定法 ${ }^{16-18)}$ により推定した分光反射率画像を利用 した血行動態イメージングについて述べる. 
ディジタルカメラで物体を撮影した場合, 画像の画素 值は，その画素位置に対応する CCD 素子に入射する光 強度や分光分布によって決定される。画素位置 $(x, y)$ に対応する CCD 素子に入射する光の分光分布は, $t_{i}(\lambda) E(\lambda) r(x, y, \lambda)$ で与えられる.ここで $r(x, y, \lambda)$ は画素座標 $(x, y)$ における物体の分光反射率， $t_{i}(\lambda), E(\lambda)$ はそれぞ れ, $i$ 番目のフィルター分光透過率, 光源の分光放射輝 度を表す。このとき，各素子に抏いて得られるセンサー 応答 $v_{i}(x, y)$ は，式 (5) で与えられる.

$$
v_{i}=\int t_{i}(\lambda) E(\lambda) S(\lambda) R(x, y, \lambda) d \lambda,
$$

ここで $S(\lambda)$ は CCD の分光感度である. 数学的な取り扱い を簡単にするため, 分光分布を離散化しべクトルや行列 を用いて表す．ディジタル RGB カラーカメラでは， $t_{i}(\lambda)$ は R， G，B の計 3 チャンネルであり，vを R， G， B の 3 チャンネルのセンサー応答を表した 3 つの要素をもつ ベクトル， $\mathbf{r}$ を物体の分光反射率を表す $\mathrm{N}$ 個の要素で構 成されるべクトルとした場合，式（5）は以下の式（6） のように表される。

$$
\mathbf{v}=\mathbf{F r} \text {. }
$$

ここでは，座標 $(x, y)$ を省略した. 行列 $\mathbf{F}$ は，カメラの $\mathrm{R}, \mathrm{G}, \mathrm{B}$ の 3 つのチャンネルの分光感度を表す行列 $\mathbf{S}$ と 光源の分光放射輝度を表す行列 $\mathbf{E}$ を用いて式（7）で定 義される。

$$
\mathbf{F}=\mathbf{E S} \text {. }
$$

$\mathrm{R}, \mathrm{G}, \mathrm{B}$ のセンサー応答ベクトル $\mathbf{v}$ と分光反射率の推定 值ベクトル $\mathbf{r}_{\text {est }}$ の間に式（8）を仮定する.

$$
\mathbf{r}_{e s t}=\mathbf{W} \mathbf{v}
$$

ここで，行列 W は Wiener 推定行列を表す. Wiener 推定 法では式（6）に示されるオリジナルの分光反射率べクト ル $\mathbf{r}$ と推定された分光反射率べクトル $\mathbf{r}_{e s t}$ の間の平均二 乗誤差 $e$ を最小とする行列 $\mathbf{W}$ を統計的に決定する.

$$
e=\left\langle\left(\mathbf{r}-\mathbf{r}_{e s t}\right)^{t}\left(\mathbf{r}-\mathbf{r}_{e s t}\right)\right\rangle
$$

ここで〈〉は分光反射率サンプルに対するアンサンブ ル平均を表す。式（9）は式（8）を用いて式（10）のよ うに表すことができる。

$$
e=\left\langle\mathbf{r}^{t} \mathbf{r}\right\rangle-\mathbf{W}\left\langle\mathbf{r}^{t} \mathbf{v}\right\rangle-\mathbf{W}^{t}\left\langle\mathbf{v}^{t} \mathbf{r}\right\rangle+\mathbf{W}^{t} \mathbf{W}\left\langle\mathbf{v}^{t} \mathbf{v}\right\rangle
$$

ここで， $e$ を最小化する条件は， $e$ を Wで偏微分したも のが 0 という式（11）で表される.

$$
\frac{\partial e}{\partial \mathbf{W}}=-\left\langle\mathbf{r}^{t} \mathbf{v}\right\rangle+\mathbf{W}^{t}\left\langle\mathbf{v}^{t} \mathbf{v}\right\rangle=0
$$

式（11）をWについて解くと，

$$
\mathbf{W}^{t}=\left\langle\mathbf{r}^{t} \mathbf{v}\right\rangle\left\langle\mathbf{v}^{t} \mathbf{v}\right\rangle^{-1}=\mathbf{R}_{r v} \mathbf{R}_{v v}{ }^{-1}
$$

が得られる.ここで， $\mathbf{R}_{r v}$ および $\mathbf{R}_{v v}$ はそれぞれ $\mathbf{r}$ と $\mathbf{v}$ 自己相関行列および相互相関行列であり，式 (12)より,

$$
\begin{aligned}
& \mathbf{R}_{r v}=\left\langle\mathbf{r} \mathbf{v}^{t}\right\rangle=\mathbf{R}_{r r} \mathbf{F}^{t}, \\
& \mathbf{R}_{v v}=\left\langle\mathbf{v} \mathbf{v}^{t}\right\rangle=\mathbf{F} \mathbf{R}_{r r} \mathbf{F}^{t},
\end{aligned}
$$

が得られる. 式（13）と式（14）を式（12）に代入する と, 推定行列 $\mathbf{W}$ は,

$$
\mathbf{W}=\mathbf{R}_{r r} \mathbf{F}^{t}\left(\mathbf{F} \mathbf{R}_{r r} \mathbf{F}^{t}\right)^{-1}
$$

として求めることが出来る. 本研究では, 分光器により 実測した多数のヒト皮膚分光反射率サンプルから自己相 関行列 $\mathbf{R}_{r r}$ を求め，式（15）の関係に基づき事前に推定 行列 $\mathbf{W}$ を決定する。 この際，光源の分光放射輝度 $\mathbf{E}$ お よびカメラの分光感度 $\mathbf{S}$ は使用機器の公称值を利用す る.4.で述べたプロセスを分光反射率画像の各画素位置 $(x, y)$ に適用することで $C_{m}, C_{h b t}$ および $\mathrm{StO}_{2}$ のイメージ ングが可能となる ${ }^{19)}$. Fig.4 は，3.で示した二層構造ファ ントムを用いて, Wiener 推定により得られた拡散反射ス
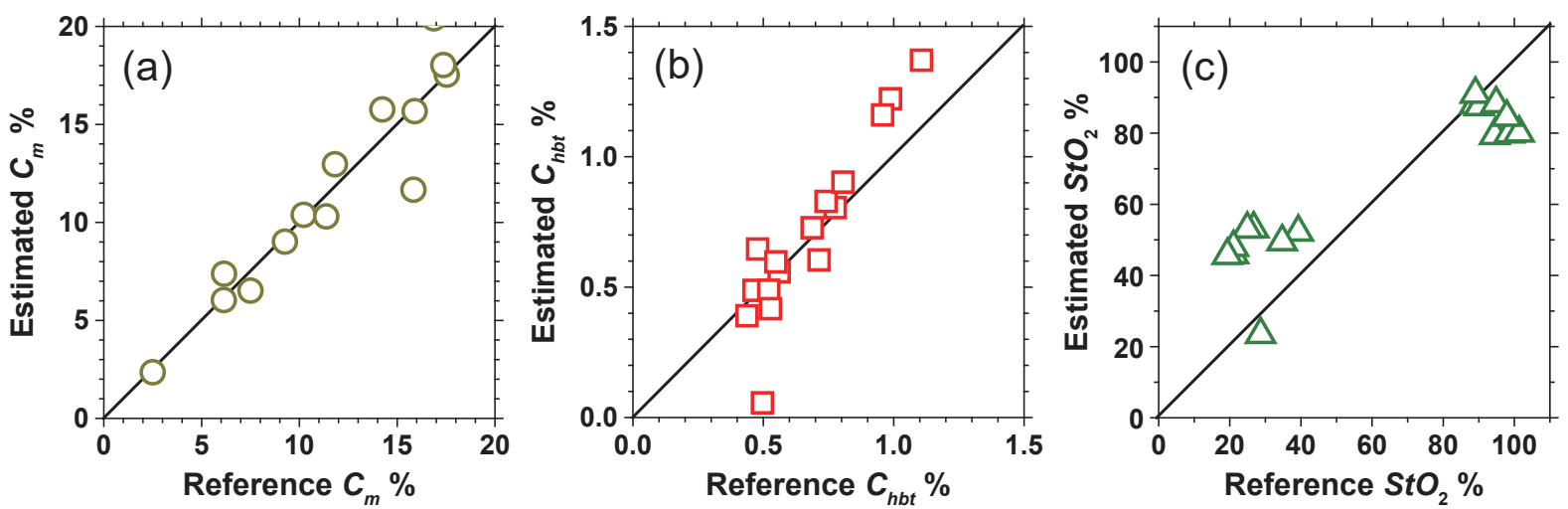

Fig.4 Comparison of the estimated values by the Wiener estimation and the reference values by spectrometer for (a) $C_{m}$, (b) $C_{h b t}$, and (c) $\mathrm{StO}_{2}$ in the phantom experiments. 


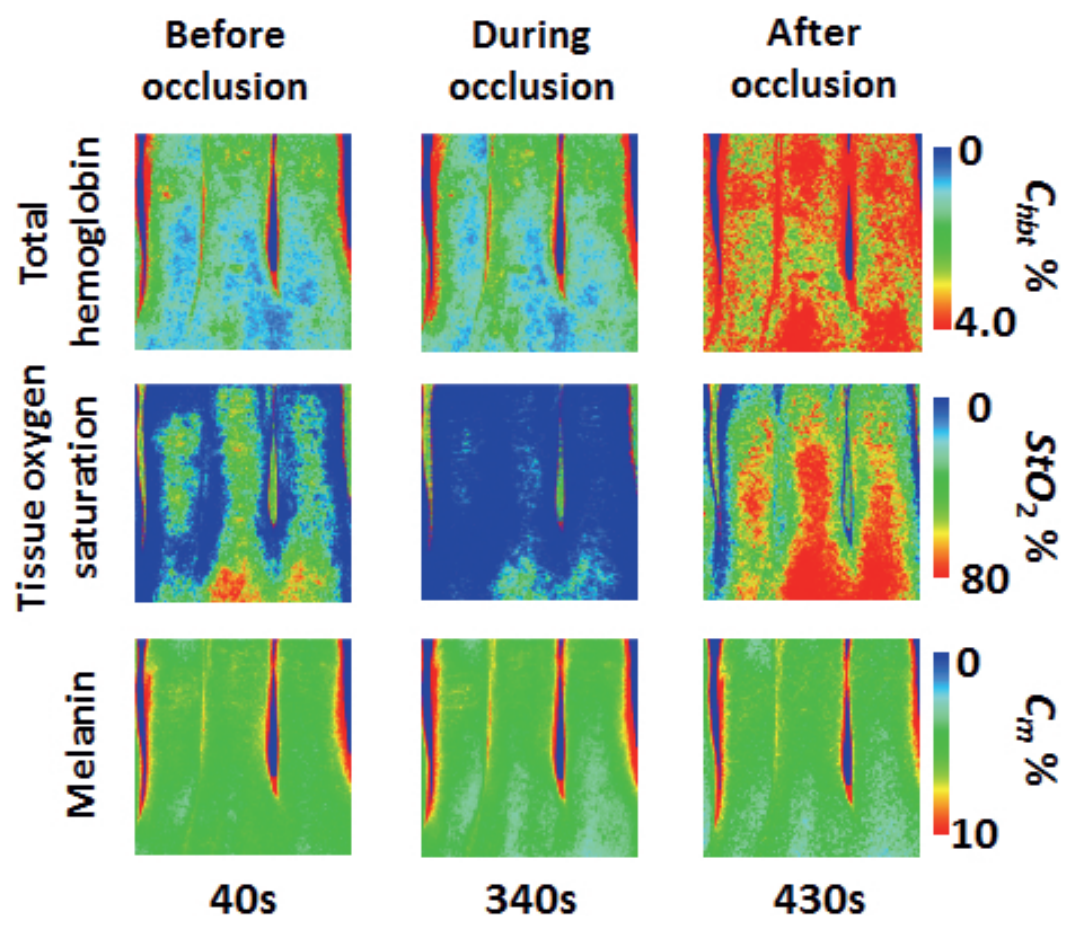

Fig.5 Typical images of fingers (from top to bottom; $C_{h b t}, S t O_{2}$ and $C_{m}$ ) before and during upper arm occlusion with pressure cuff, and immediately after deflation of pressure cuff.

ペクトル解析法の結果の妥当性について検討した結果で あり, 本方法により得られた $C_{m}, C_{h b t}$ 扩よび $\mathrm{StO}_{2}$ の推 定值は分光器で測定した拡散反射スペクトルから推定し た参照値に対して良好な結果を示していることが分かる.

本方法の生体に対する有用性を確認するために，ヒ卜 を対象とした上腕部の圧迫一解放実験を行った。 ヒ上を 対象とした実験は, 東京農工大学研究倫理委員会の承認 を受け，被験者からインフォームド・コンセントを得た 後に行われた. Fig. 5 にヒト上腕を $250 \mathrm{mmHg}$ の圧力で圧 迫した際の色素濃度画像の一例を示す. 血流閉塞に伴い 全血液濃度 $C_{h b t}$ はわずかに増加し, 組織酸素飽和度 $S t O_{2}$ は低下する. 血流の再開により $C_{h b t}$ と $\mathrm{StO}_{2}$ は急激な増加 を示す.この結果は動脈血流入の停止による脱酸素化血 液濃度の相対的な増加と, 血流再開後の反応性充血に伴 う動脈血流入量すなわち酸素化血液濃度の増加を表して いると考えられる。一方で血流とは無関係なメラニン濃 度 $C_{m}$ は終始一定の值を示している。 Fig.6 は, 15 fps (frame per second) で連続測定した指先の RGB 動画像か ら得られた $C_{h b t}$ の時間変化から脈波成分を抽出した結果 である。一般的なパルスオキシメーターで観察される二 峰性の容積脈波と同様の信号が得られているのがわかる. 指先以外の, 手, 前腕, 顔などの部位に打いても脈波成 分の抽出が可能であり, 容積脈波の非接触イメージング にも成功している20).

\section{6. 吸収・散乱スペクトル画像の推定と脳組織バイアビリ ティイメージング}

近年, 光学的手法 21-26)を用いて in vivo ラット露出脳に おける脳神経組織のバイアビリティや神経活動を評価す る試みがなされている. 脳組織における主要な光学特性

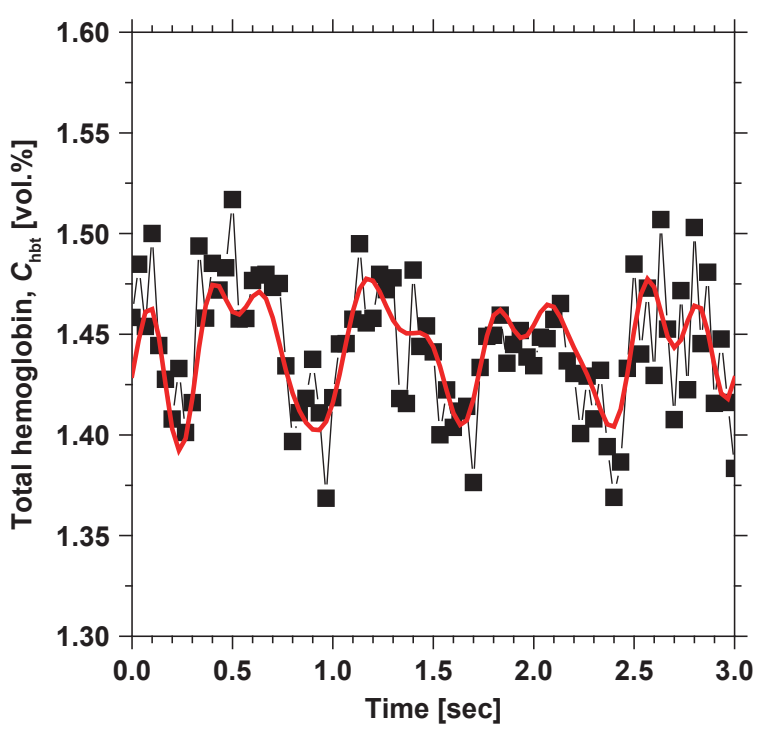

Fig.6 Typical plethysmogram extracted from the time course of $C_{h b t}$ averaged over the region of interest on in vivo human fingertip.

変化は, 脳血流の増減やへモグロビンの酸素化・脱酸素 化による光吸収変化, 細胞外イオン濃度変化により生じ る浸透圧に依存した細胞体積変化に起因する光散乱変化

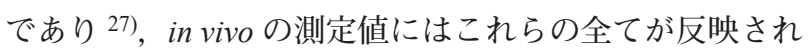
ると考えられる。著者らは5.で述べた皮膚色素濃度定量 イメージング法を発展させることで, 露出脳表面の拡散 反射率画像から吸収特性と散乱特性を同時にイメージン グする方式を新たに開発した ${ }^{28)}$. 脳組織の主要な吸収体 
として酸素化へモグロビンと脱酸素化へモグロビンを考

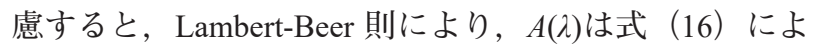
り表わされる.

$$
A(\lambda)=C_{h b o} l(\lambda) \varepsilon_{h b o}(\lambda)+C_{h b d} l(\lambda) \varepsilon_{h b d}(\lambda)+S(\lambda) .
$$

ここで， $C, l(\lambda), \varepsilon(\lambda)$ はそれぞれ色素濃度，平均光路長 およびモル吸光係数を，また $S(\lambda)$ は散乱による減衰項を 表わす. 式（16）に対し, 吸光度スペクトルを目的変数 とし, 各色素のモル吸光係数を説明変数とした重回帰分 析を行なうと, 式（17）の重回帰式で表現される回帰係 数 $\alpha_{h b o}, \alpha_{h b d}$ および $\alpha_{0}$ が得られる.

$$
A(\lambda)=\alpha_{h b o} \varepsilon_{h b o}(\lambda)+\alpha_{h b d} \varepsilon_{h b d}(\lambda)+\alpha_{0} .
$$

これらの回帰係数は，酸素化へモグロビン，脱酸素化へ モグロビンの濃度および等価散乱係数 $\mu_{s}{ }^{\prime}(\lambda)$ に依存す る29). 脳組織をはじめ, 生体の軟組織の $\mu_{s}{ }^{\prime}(\lambda)$ は波長 $\lambda$ の 増加に対して単調に減衰する分光特性を示すため，式 （18）で表される累乗関数により近似することが可能である.

$$
\mu_{s}{ }^{\prime}(\lambda)=a \lambda^{-b}
$$

係数 $a$ および指数 $b$ は組織内の細胞および細胞内小器官 の数密度およびサイズを反映する ${ }^{30,31)}$. 本研究では，回 帰係数 $\alpha_{h b o}, \alpha_{h b d}, \alpha_{0}$ を変数として, 式 (19)，(20), お よび（21）により酸素化へモグロビン濃度 $C_{h b o}$, 脱酸素 化へモグロビン濃度 $C_{h b d}$, および指数 $b$ を推定する. ま た, 係数 $a$ の推定に打いて, 回帰係数 $\alpha_{h b o}, \alpha_{h b d}, \alpha_{0}$ に, 指数 $b$ を変数として加えることで，推定結果が改善する ことが分かっている，そこで，式（22）により係数 $a$ を 推定する.

$$
C_{h b o}=\boldsymbol{\beta}_{h b o} \cdot \boldsymbol{\alpha}_{1},
$$

$$
\begin{aligned}
& C_{h b d}=\boldsymbol{\beta}_{h b d} \cdot \boldsymbol{\alpha}_{1}, \\
& b=\boldsymbol{\beta}_{b} \cdot \boldsymbol{\alpha}_{1}, \\
& a=\boldsymbol{\beta}_{a} \cdot \boldsymbol{\alpha}_{2} .
\end{aligned}
$$

ここで， $\boldsymbol{\alpha}_{1}$ は $\alpha_{h b o}, \alpha_{h b d}, \alpha_{0}$ から成るべクトルを，また， $\boldsymbol{\alpha}_{2}$ は $\alpha_{h b o}, \alpha_{h b d}, \alpha_{0}, b$ から成るべクトルを表わす. $\boldsymbol{\beta}_{h b o}$, $\boldsymbol{\beta}_{h b d}, \boldsymbol{\beta}_{b}$, および $\boldsymbol{\beta}_{a}$ は回帰係数 $\alpha_{h b o}, \alpha_{h b d}, \alpha_{0}$ から $C_{h b o}$, $C_{h b d}, \quad b, a$ を得るための係数べクトルであり, $\mu_{s}{ }^{\prime}(\lambda)$ と $\mu_{a}(\lambda)$ をパラメーターとした MCS により算出した脳組織 の分光反射率の結果から統計的に決定することができる. 脳組織の吸収係数スペクトル $\mu_{a}(\lambda)$ は，推定された $C_{h b o}$ と $C_{h b d}$ を用いて式 (23) の関係から求めることが出来る.

$$
\mu_{a}(\lambda)=C_{h b o} \varepsilon_{h b o}(\lambda)+C_{h b d} \varepsilon_{h b d}(\lambda)
$$

また，全へモグロビン濃度 $C_{h b t}$ は $C_{h b o}$ と $C_{h b d}$ の和とし て, さらに, 組織酸素飽和度 $\mathrm{StO}_{2}$ は $\mathrm{StO}_{2}=C_{h b o} /\left(C_{h b o}+\right.$ $\left.C_{h b d}\right)$ より算出する.

本方法の in vivo 脳組織への応用可能性を検討するため に，ラットを用いた動物実験を行った。動物実験は東京 農工大学研究倫理委員会動物実験小委員会の承認を得て 行われた. 実験では $\alpha$-クロラロース $55 \mathrm{mg} / \mathrm{kg}$ とカルバミ ド酸エチル $600 \mathrm{mg} / \mathrm{kg}$ の混合麻酔を腹腔投与したウィス ター種雄性ラットの頭部を切開し, 精密ドリルを用いて, 右頭頂部分の頭蓋骨に楕円状の穴を形成し，ラット脳を 露出させた. 高輝度白色 LED 光源からの白色光は, リン グライトガイドを介してラット露出脳へ照射し，ラット 露出脳表面からの拡散反射光は RGBCCD カメラにより 反射光強度画像として撮影・保存した。長波長域におけ る十分な検出光量を確保するために CCD 前面の近赤外 カットフィルターは除去している.

Fig.7 に吸入酸素濃度 $\mathrm{FiO}_{2}$ が $20.9 \%$ の条件下において, ラット脳表から得られた $C_{h b o}, C_{h b d}, C_{h b t}, \mathrm{StO}_{2}$, 散乱パ

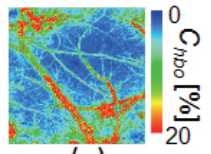

(a)

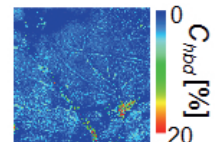

(b)

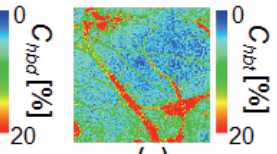

(c)

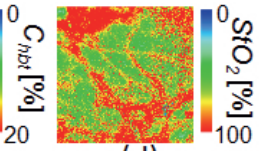

(d)

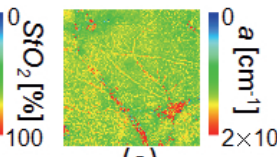

(e)

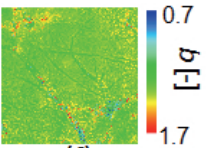

(f)

(g)

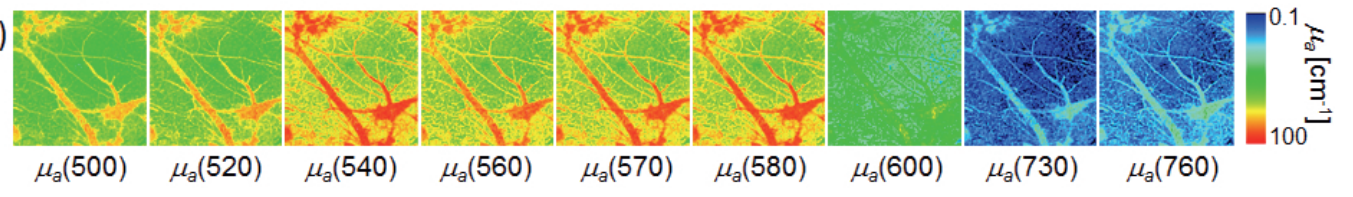

(h) $-?$

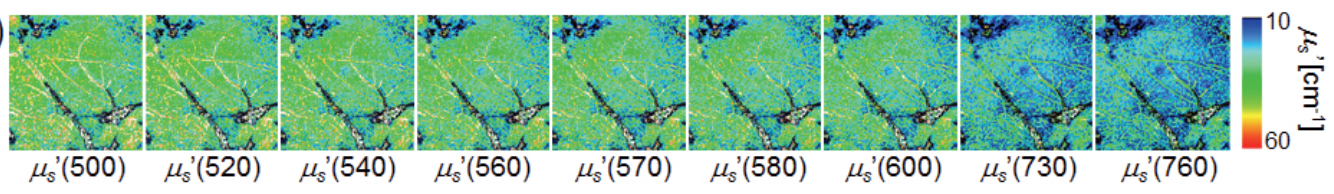

Fig.7 Typical estimated images of exposed rat brain obtained using the proposed method under normoxia $\left(\mathrm{FiO}_{2}=20.9 \%\right)$ for (a) oxygenated hemoglobin $C_{h b o}$, (b) deoxygenated hemoglobin $C_{h b d}$, (c) total hemoglobin $C_{h b t}$, (d) tissue oxygen saturation $\mathrm{StO}_{2}$, (e) scattering amplitude $a$, (f) scattering power $b$, (g) absorption coefficient $\mu_{a}(\lambda)$ and (h) reduced scattering coefficient $\mu_{s}^{\prime}(\lambda)$. 
ラメーター $a$, 散乱パラメーター $b, \mu_{a}(\lambda)$ および $\mu_{s}{ }^{\prime}(\lambda)$ の 画像を示す。また, Fig. 8 に異なる吸入酸素濃度条件下の ラット脳表から得られた原 RGB 画像, $C_{h b o}, C_{h b d}, C_{h b t}$, $\mathrm{StO}_{2}$, 打よび波長 $500 \mathrm{~nm}$ に打ける $\mu_{s}{ }^{\prime}(500)$ の画像を示す. 高酸素状態では $C_{h b o}$ は増加し, $C_{h b d}$ は減少を示し, $\mathrm{StO}_{2}$ は増加する。無酸素状態の開始後, $C_{h b o}$ は減少し, $C_{h b d}$ は増加を示し, $\mathrm{StO}_{2}$ は減少する。 $\mathrm{C}_{h b t}$ は呼吸停止の直前 から顕著な増加を示し，これは低酸素状態を補償するた めの脳血流の増加を反映していると考えられる。一方で, $\mu_{s}{ }^{\prime}(500)$ は無酸素状態の開始後に減少を示し, 呼吸停止後 に増加に転じる。無酸素状態により酸素の供給が断たれ た場合，ミトコンドリアの呼吸が阻害されるため，ATP の産生が減少する. ATP 産生の減少は $\mathrm{Na}^{+} / \mathrm{K}^{+}$ATPase ポ
ンプの破綻を引き起こし，細胞外 $\mathrm{Na}^{+}, \mathrm{Cl}^{-}, \mathrm{Ca}^{2+}$ が細胞 内に流入することで，浸透圧により細胞外の水が細胞 内に移行し，細胞や細胞内小器官は膨潤する（Cell swelling) ことが報告されている32,33)。また，長時間の無 酸素状態は神経細胞の不可逆的な形態変化を引き起こ し，樹状突起が多数のビーズ状に変形する（Dendritic beading）ことで透過光強度が減少することが報告されて いる ${ }^{32,33)}$. 従って, 呼吸停止後において観察された $\mu_{s}^{\prime}$ の 変化は神経組織のバイアビリティ低下に伴う細胞・細胞 内小器官の不可逆的な形態変化を反映している可能性が ある。

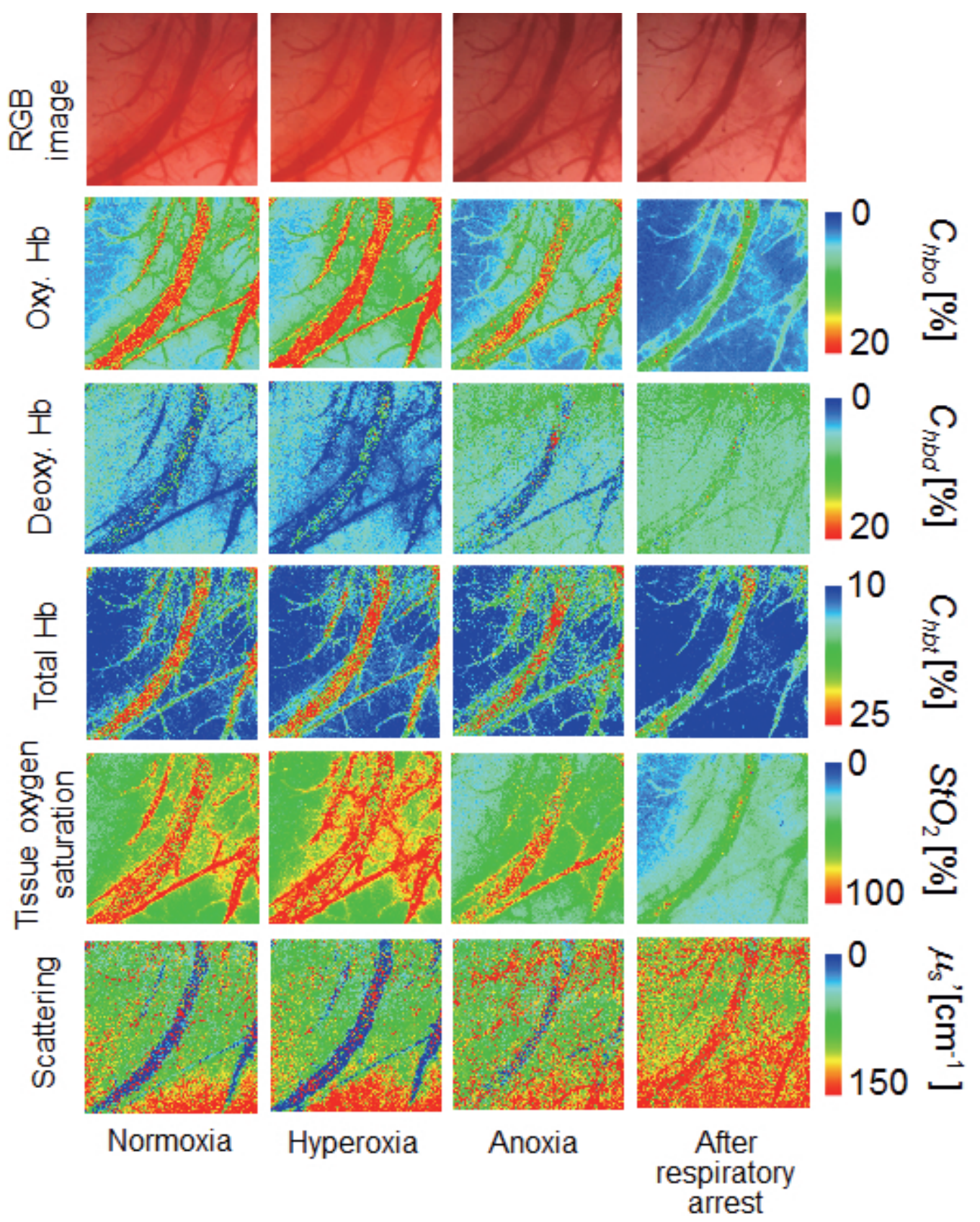

Fig.8 Typical images for in vivo results while varying $\mathrm{FiO}_{2}$ (from top to bottom: RGB image, $C_{h b o}, C_{h b d}, C_{h b t}, S t O_{2}$, and $\mu_{s}$ '(500)). 


\section{7. おわりに}

本稿では, 生体内の光伝搬モンテカルロシミュレーショ ンの結果を利用した生体組織の拡散反射分イメージング 法について，著者らの研究を中心に述べた．また，光学 的診断・治療法の新規開発において有用な光学的ファン トムについて紹介した。本稿で述べた定常白色光源を用 いた拡散反射分光法はシンプルな計測システムで実現可 能であり，他の光学的計測技術との併用も比較的容易に 行うことが出来ると考えられる. また, 内視鏡技術と組 み合わせることで，適用範囲の拡大も見込まれる．皮膚 血行動態や脈波のイメージングは酸素モニターやバイタ ルサインとしての利用のみならず，動脈硬化や糖尿病等 と関連する末梢血管内皮機能の非侵襲的評価法としての 可能性も有している. また, 脳組織光学特性值の in vivo イメージングは, 外科手術中の組織のバイアビリティ診 断などへの応用も期待できる.

\section{利益相反の開示}

利益相反なし。

\section{引用文献}

1) Tuchin VV. Tissue Optics: Light Scattering Methods and Instruments for Medical Diagnostics, 2nd ed. SPIE Press; 2007.

2) van Gemert MJC, Jacques SL, Sterenborg HJCM, Star WM. Skin optics. IEEE Trans Biomed Eng. 1989; 36: 1146-1154.

3) van der Zee P, Essenpreis M, Delpy DT. Optical properties of brain tissue. Proc. SPIE. 1993; 1888: 454-465.

4) Wang L-H, Jacques SL, Zheng LQ. MCML-Monte Carlo modeling of photon transport in multi-layered tissues. Comput Methods Programs Biomed. 1995; 47: 131-146.

5) Pogue BW, Patterson MS. Review of tissue simulating phantoms for optical spectroscopy, imaging and dosimetry. J Biomed Opt. 2006; 11: 041102.

6) Firbank M, Oda M, Delpy DT. An improved design for a stable and reproducible phantom material for use in nearinfrared spectroscopy and imaging. Phys Med Biol. 1995; 40: 955-961.

7) Hebden JC, Hall DJ, Firbank M, Delpy DT. Timeresolved optical imaging of a solid tissue-equivalent phantom. Appl Opt. 1995; 34: 8038-8047.

8) Firbank M, Delpy DT. A phantom for the testing and calibration of near-infrared spectrometers. Phy Med Biol. 1994; 39: 1509-1513.

9) Sukowski U, Schubert F, Grosenick D, Rinneberg H. Preparation of solid phantoms with defined scattering and absorption properties for optical tomography. Phys Med Biol. 1996; 41: 1823-1844.

10) Mustari A, Nishidate I, Wares MA, Maeda T, Kawauchi $S$, Sato S, Sato M, Aizu Y. Agarose-based Tissue Mimicking Optical Phantoms for Diffuse Reflectance Spectroscopy. J Vis Exp. 2018; 138.

11) Kennedy BF, Loitsch S, McLaughlin RA, Scolaro L, Rigby P, Sampson DD. Fibrin phantom for use in optical coherence tomography. J Biomed Opt. 2010; 15: 030507.

12) Kim C, Wang LV. Multi-optical-wavelength ultrasoundmodulated optical tomography: a phantom study. Opt Lett. 2007; 32: 2285-2287.
13) Xu Z, Li C, Wang LV. Photoacoustic tomography of water in phantoms and tissue. J Biomed Opt. 2010; 15: 036019.

14) Nishidate I, Aizu Y, Mishina H. Estimation of melanin and hemoglobin in skin tissue using multiple regression analysis aided by Monte Carlo simulation. J Biomed Opt. 2004; 9: 700-710.

15) Nishidate I, Wiswadarma A, Hase $Y$, Tanaka N, Maeda $T$, Niizeki K, Aizu Y. Noninvasive spectral imaging of skin chromophores based on multiple regression analysis aided by Monte Carlo simulation. Opt Lett. 2011; 36: 3239-3241.

16) Stigell P, Miyata K, Kansari MH. Wiener estimation method in estimating of spectral reflectance from RGB image. Patt Recogn Image Anal. 2007; 17: 233-242.

17) Murakami Y, Fukura K, Yamaguchi M, Ohyama N. Color reproduction from low-SNR multispectral images using spatio-spectral Wiener estimation. Opt Express. 2008; 16: 4106-4120.

18) Chen S, Liu Q. Modified Wiener estimation of diffuse reflectance spectra from RGB values by the synthesis of new color for tissue measurements. J Biomed Opt. 2012; 17: 030501.

19) Nishidate I, Maeda T, Niizeki K, Aizu Y. Estimation of Melanin and Hemoglobin Using Spectral Reflectance Images Reconstructed from a Digital RGB Image by the Wiener Estimation Method. Sensors. 2013; 13: 7902-7915.

20) Nishidate I, Matsuda R, Tanaka N, Maeda T, Yuasa T, Yuasa T, Niizeki K, Aizu Y. Noncontact plethysmographic imaging based on diffuse reflectance spectroscopy using a digital RGB camera. Proc SPIE. 2013; 8798: 87980D.

21) Kawauchi $S$, Sato $S$, Ooigawa $H$, Nawashiro $H$, Ishihara $M$, Kikuchi M. Simultaneous measurement of changes in light absorption due to the reduction of cytochrome c oxidase and light scattering in rat brains during loss of tissue viability. Appl Opt. 2007; 47: 4164-4176.

22) Kawauchi $S$, Sato $S$, Ooigawa $H$, Nawashiro $H$, Ishihara $M$, Kikuchi M. Light scattering change precedes loss of cerebral adenosine triphosphate in a rat global ischemic brain model. Neurosci Lett. 2009; 459: 152-156.

23) Rajagopalan UM, Tanifuji M. Functional optical coherence tomography reveals localized layer-specific activations in cat primary visual cortex in vivo. Opt Lett. 2007; 32: 2614-2616.

24) Sato M, Hrebesh MS, Nishidate I. Measurement of signal intensity depth profiles in rat brains with cardiac arrest using wide-field optical coherence tomography. Appl Opt. 2009; 48: 4354-4364.

25) Sato M, Nomura D, Tsunenari T, Nishidate I. Measurement of signal intensity depth profiles in rat brains with cardiac arrest maintaining primary temperature by wide-field optical coherence tomography. Appl Opt. 2010; 49: 4851-4858.

26) Sato $M$, Nomura $D$, Tsunenari $T$, Nishidate I. In vivo rat brain measurements of changes in signal intensity depth profiles as a function of temperature using wide-field optical coherence tomography. Appl Opt. 2010; 49: 5686-5896.

27) Bonhoeffer T, Grinvald A. Optical Imaging based on intrinsic signals: the methodology. Toga AW, Mazziotta JC. (eds.) Brain mapping; the methods. San Diego: Academic Press; 1996. p. 55-97.

28) Yoshida K, Nishidate I, Ishizuka T, Kawauchi S, Sato S, Sato M. Multispectral imaging of absorption and scattering properties of in vivo exposed rat brain using a digital red- 
green-blue camera. J Biomed Opt. 2015; 20: 051026.

29) Kawauchi S, Nishidate I, Uozumi Y, Nawashiro H, Ashida H, Sato S. Diffuse light reflectance signals as potential indicators of loss of viability in brain tissue due to hypoxia: chargecoupled-device-based imaging and fiber-based measurement. J Biomed Opt. 2013; 18: 015003.

30) Mourant JR, Fuselier T, Boyer J, Johnson T, Bigio IJ. Mechanisms of light scattering from biological cells relevant to noninvasive optical-tissue diagnostics. Appl Opt. 1998; 37 : 3586-3593.

31) Wang X, Pogue BW, Jiang S, Song X, Paulsen KD, Kogel C, Poplack SP, Wells WA. Approximation of Mie scattering parameters in near-infrared tomography of normal breast tissue in vivo. J Biomed Opt. 2005; 10: 051704.

32) Jarvis CR, Anderson TR, Andrew RD. Anoxic depolarization mediates acute damage independent of glutamate in neocortical brain slices. Cereb Cortex. 2001; 11: 249-259.

33) Anderson TR, Jarvis CR, Biedermann AJ, Molnar C, Andrew $\mathrm{RD}$. Blocking the anoxic depolarization protects without functional compromise following simulated stroke in cortical brain slices. J Neurophysiol. 2005; 93: 963-979. 